\title{
Climate change is eliminating Pinguicula macroceras Link habitat
}

In Montana

NAtCh GREYes • 272 N. Main Street, Apt. 2 - Concord - New Hampshire 03301 - USA •natch.greyes@gmail.com

Keywords: climate change, Pinguicula macroceras, Montana, Glacier National Park.

The damage caused by climate change to plant communities is often obscured by a confluence of causes and vague deadlines, but in Montana there is an exception to that trend. The National Park Service in Montana has been leading efforts to document glacial melting. In the process, they have incidentally recorded ongoing damage to the handful of colonies of Pinguicula macroceras Link (Rice et al. 2008) that occur in Glacier National Park.

Pinguicula macroceras is a rare species in Montana (Anon. 2013b). It occurs only in the alpine zone of Glacier National Park (Fig. 1) and relies heavily on glacial melt for its water supply (Bloom, pers. corresp.). Since 1933, twelve colonies, in six mapped clusters, have been discovered (Anon 2013a). At least seven of those colonies, comprising five clusters, are found in areas likely fed by glacial melt (Anon 2013a).

Historically, P. macroceras has been documented north of Logan Pass, at Grinnell Lake, Grinnell Falls, and at Iceberg Lake (Casper 1962). More recently, P. macroceras has been documented at six different locations with seven colonies in the central part of Glacier National Park ranging from the head of Swiftcurrent Creek southeast to Blyth Creek and five colonies along Lee Creek, including the well-known populations along the "weeping wall" near Logan Pass (Bloom, pers. corresp.). Most observed colonies range in density from one to seven plants (Bloom, pers. corresp.; Anon 2013b).

Since 1900, the mean annual temperature for Glacier National Park and its surrounding region has increased $1.3^{\circ} \mathrm{C}$, which, combined with longer and hotter summers, less snowfall and more rain, has led to unsustainably increasing glacier melt rates (Fagre 2013). Ordinarily, glaciers act as slow-releasing banks of water for alpine regions. While winter snowpack is helpful in supplying plants with water during the beginning of their growing season, by midsummer's end the winter snowpack has usually finished melting. At that point, glacial runoff is the only reliable water supply for alpine communities.

The largest colony observed to date by the author in the central part of the park, was approximately $6 \mathrm{~km}$ along a popular alpine hiking trail. The precise location of this colony is being withheld to prevent poaching. This location holds approximately thirty plants. The colony exists in the tiny S-bend of a small alpine stream fed by glacial melt, which traverses the alpine trail at an elevation of approximately $1600 \mathrm{~m}$. At that location, there is no protection from the glaring sun or the deep snow packs that cover the

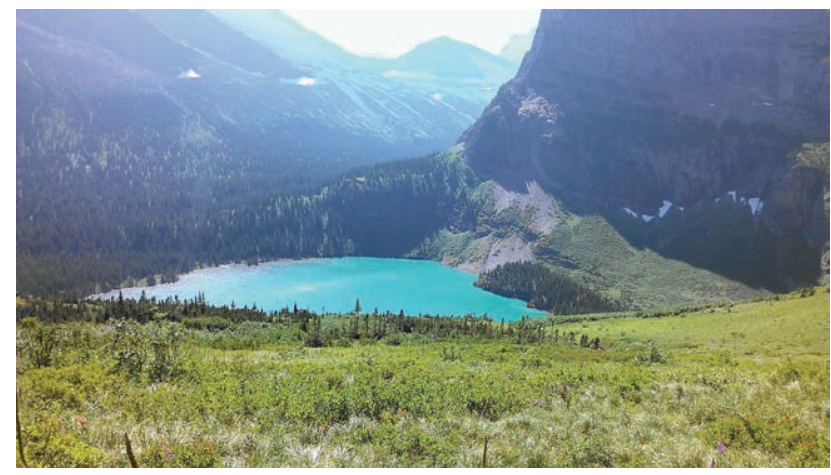

Figure 1: Typical alpine habitat in Glacier National Park, Montana. 
mountainside for months on end. The plant species face a constant threat of desiccation due to the harsh, dry winds that blow over the craggy peaks and the hot sun that beats down on the rocky alpine soil. Once the remnants of the glacier melt completely, the stream will dry and the colony will die.

The colony of $P$. macroceras is able to survive in such a harsh and arid environment only because of the intersection of the nearly-vertical stream formed by glacial melt and a large boulder positioned in a way that allows a slow, steady stream of water to seep over its surface. That seeping water is just slow enough that a spongy moss has been able form a stable growing environment for P. macroceras and associated non-carnivorous plants.

Current projections indicate that the glacier located $300 \mathrm{~m}$ above the plants will be gone by 2020 (Minard 2009). The alpine ecosystem here, like most alpine ecosystems throughout Glacier National Park and the surrounding region, has a poor soil that does not retain water well. Once the remnants of the glacier finish melting, the slow, continuous release of water that feeds the stream will stop, and the vegetation that depends on it, including the colony of P. macroceras, will become desiccated and die.

Of the six mapped occurrences of $P$. macroceras within Montana, at least three occur near a stream fed by glacial melt and two others occur near lakes left by retreating glaciers (Anon. 2013b). While the continued existence of the colonies upon the shores of the lakes left by retreating glaciers may persist for a time, the colonies that occur near streams fed by glacier melt will almost certainly perish by the time the last glaciers have left Glacier National Park (Fagre 2013).

\section{References}

Anon. 2013a. Pinguicula vulgaris. University of Montana Herbarium. http://herbarium.dbs.umt. edu/database/DisplayItem.aspx?id=Pinguicula\%20vulgaris, accessed 30 September 2013.

Anon. 2013b. California Butterwort - Pinguicula macroceras. Montana Field Guide. Montana Natural Heritage Program. http://FieldGuide.mt.gov/detail_PDLNT01040.aspx, accessed 30 September 2013.

Bloom. S. 2013. Personal Correspondence. 24 September 2013. On file with author.

Casper, S.J. 1962. On Pinguicula macroceras Link in North America. Rhodora 64(759): 212-22.

Fagre, D. 2013. Glacier monitoring studies. Northern Rocky Mountain Science Center (NOROCK). United States Geological Survey. http://www.nrmsc.usgs.gov/research/glaciers.htm, accessed 30 September 2013.

Goldstein, A., and Howard, K. 2013. Glacier National Park prepares for ice-free future. News Watch. National Geographic Water Currents. http:/newswatch.nationalgeographic.com/2013/09/10/ glacier-national-park-prepares-for-ice-free-future/, accessed 30 September 2013.

Minard, A. 2009. No more glaciers in Glacier National Park by 2020? National Geographic News. http://news.nationalgeographic.com/news/2009/03/090302-glaciers-melting.html, accessed 30 September 2013.

Probatova, N.S., Barkalov, V.Y., and Rudyka, E.G. 2004. Chromosome numbers of selected vascular plant species from Sakhalin, Moneron and the Kurile Islands. Bulletin of the Hokkaido University Museum 2:15-23. http://eprints.lib.hokudai.ac.jp/dspace/handle/2115/47769, accessed 30 September 2013.

Rice, B., Yin, A., and Morimoto, G.E. 2008. Observations of isolated Pinguicula populations in the western USA. Carniv. Pl. Newslett. 37(4): 100-109. 